\title{
THE INFLUENCE OF ACCOUNTING INFORMATION SYSTEM IMPLEMENTATION AND INTERNAL CONTROL EFFECTIVENESS ON THE PERFORMANCE OF EMPLOYEES (CASE STUDY ON MICRO, SMALL, MEDIUM ENTERPRISES SUBANG REGENCY)
}

\author{
Agnes Sinta Harini, Asep Kurniawan, Indah Umiyati \\ Sekolah Tinggi Ilmu Ekonomi Sutaatmadja
}

\begin{tabular}{l}
\hline INFO ARTIKEL \\
\hline Histori Artikel : \\
Tgl. Masuk : 25 Mei 2019 \\
Tgl. Diterima : 03 Juni 2019 \\
Tersedia Online : 29 Juni \\
2019 \\
\hline Keywords: \\
accounting information \\
system, internal control and \\
performance of employees.
\end{tabular}

ABSTRAKIABSTRACT

located in the district of Subang. The purpose of this research is to find out the influence of accounting information system implementation and internal control on the performance of employees.

The method of research is quantitative method. The sample collection technique is conducted by performing non probability sampling and Purposive sampling technique approach based on certain criteria set by the researchers using a questionnaire as a data collection tool. As for which a sample of this study were 100 respondents. Data were analyzed using multiple linear regression analysis by using computer program of SSPS (Statistical Package Social Science) V.20.0 for Windows. The questionnaire was tested for validity and reliability test. In this study using a classic assumption test including normality test, multicoloniarity test, heteroskodastisitas test. As for testing the hypothesis in this study using a test determination coefficient, $F$ test and t test.

The results of the study with multiple regression indicate that (1) the accounting information system positive and significant impact on the performance of employees, (2) internal control of positive and significant effect on the performance of employees, (3) accounting information systems and internal control, simultaneously positive and significant impact on the performance of employees. The determination coefficient analysis $\left(R^{2}\right)$ is 0.566 which means that the accounting information system $\left(X_{I}\right)$ and payment punctuality of account receivable $\left(X_{2}\right)$ has influence $56,6 \%$ and the remaining is $44,4 \%$ is explained by other variables which are used in this research.

\section{PENDAHULUAN}

Perkembangan Usaha Mikro, Kecil dan Menengah (UMKM) sangat pesat dari 
tahun ke tahun. UMKM di Indonesia memiliki peranan sangat penting terutama dalam hal penyediaan lapangan pekerjaan. Pendapat ini didasarkan pada berbagai kenyataan dan fenomena yang menunjukkan bahwa kelompok usaha ini memperkerjakan lebih banyak orang dibandingkan unit-unit usaha lain. Terbukti pada saat krisis ekonomi di Indonesia tahun 1997 telah mengakibatkan jatuhnya perekonomian nasional, di tengah keterpurukan akibat krisis moneter pada berbagai sektor ekonomi, Usaha Mikro, Kecil dan Menengah (UMKM) dapat bertahan bahkan dapat menjadi pemulih perekonomian. Sektor UMKM telah mampu menunjukkan kinerja yang lebih kuat dalam menghadapi masa krisis dan UMKM juga terbukti mampu menampung $99,45 \%$ dari total tenaga kerja atau 73,24 juta tenaga kerja. UMKM merupakan potensi yang sangat strategis bagi perekonomian nasional. Hal ini disebabkan oleh menyebarnya UMKM hingga ke pelosok pedesaan serta jumlahnya yang begitu banyak (Salamah, 2010).

Jumlah pelaku usaha sektor industri Usaha Mikro, Kecil dan Menengah (UMKM) Indonesia termasuk yang paling banyak di antara negara lainnya, terutama sejak tahun 2014. Data dari Kementerian Koperasi dan Usaha Kecil Menengah pada tahun 2014, terdapat sekitar 57,9 juta pelaku UMKM di Indonesia. Beberapa tahun belakang, populasi penduduk dengan usia produktif lebih banyak dari pada jumlah lapangan pekerjaan yang tersedia. Hal ini memicu khususnya para pemuda untuk menciptakan peluangnya sendiri dengan membuka bisnis. Sebagian besar tergolong sebagai pelaku usaha sektor industri Usaha Mikro, Kecil dan Menengah (UMKM). (Kementerian Koperasi dan Usaha Kecil Menengah 2014).

Maraknya pertumbuhan ekonomi usaha sekarang ini menciptakan kondisi persaingan yang semakin ketat, keadaan ini memaksa para pelaku usaha berlombalomba untuk memenangkan persaingan. Terutama pembentukan pasar tunggal atau pasar bebas yang diistilahkan dengan Masyarakat Ekonomi Asean (MEA) sudah diberlakukan sejak awal tahun 2016 yang akan mempengaruhi banyak orang dan pada sektor-sektor tertentu. Pembentukan pasar bebas ini nantinya memungkinkan satu negara menjual barang dan jasa dengan mudah ke negara-negara lain di seluruh Asia Tenggara sehingga kompetisi akan semakin ketat. Belum lagi situasi yang mengharuskan negara indonesia bersaing secara global dengan negara-negara regional asia tenggara lainnya dengan adanya pasar bebas ASEAN. Hal ini memaksa para pelaku usaha untuk memproduksi barang atau jasa yang 
berkualitas dengan harga yang dapat bersaing. (Khairiyah 2017)

Dengan semakin mengglobalnya perekonomian dunia dan era perdagangan bebas usaha mikro, kecil dan menengah (UMKM) di indonesia juga diharapkan dapat menjadi salah satu peran penting. UMKM diharapkan sebagai pencipta pasar didalam maupun diluar negeri dan sebagai salah satu sumber penting bagi surplus neraca perdagangan dan jasa atau neraca pembayaran. Untuk melaksankan peranan tersebut, UMKM Indonesia harus membenahi diri, yakni menciptakan daya saing globalnya (Yonathan., Ronald Sukwandi. 2014).

Secara legal UMKM diatur dalam Undang-Undang No. 20 Tahun 2008 tentang UMKM. Berdasarkan pada undang-undang tersebut usaha mikro, kecil dan menengah diberi batasan-batasan sehingga ada kategori tertentu yang menentukan usaha tersebut termasuk usaha mikro, kecil dan menengah. Secara umum definisi dan kategori usaha mikro, kecil dan menengah merupakan usaha produktif yang berdiri sendiri yang di kelola perorangan atau badan usaha yang memiliki kekayaan bersih tidak lebih dari Rp. 10.000.000.000,- (sepuluh miliyar rupiah) tidak termasuk tanah dan bangunan tempat usaha dan hasil penjualan tidak lebih dari Rp. 50.000.000.000,- (Lima puluh miliyar rupiah).

UMKM memang menjadi peran sentral dalam perekonomian Indonesia. UMKM telah teruji mampu bertahan di tengah krisis ekonomi yang melanda perekonomian global. Persaingan yang ketat menuntut UMKM untuk lebih efektif dan efisien dalam menjalankan kegiatan operasionalnya. Selain itu terdapat pula permasalahan-permasalahan lain yang harus dihadapi, seperti keterbatasan tingkat kemampuan, keterampilan, keahlian, manajemen sumber daya manusia, kewirausahaan, pemasaran dan keuangan. Permasalahan-permasalahan yang di atas dapat diatasi atau dikurangi dengan cara menjaga efisiensi dan efektifitas perusahaan. Efektifitas dan efisiensi sangat erat hubunganya dengan sistem pengendalian internal. Pengendalian internal membantu manajemen untuk mencapai tujuan perusahaan secara efektif dan efisien. Pengendalian internal merupakan suatu cara untuk mengarahkan, mengawasi dan mengukur sumber daya perusahaan. Manajemen dapat menggunakan pengendalian internal untuk merencanakan dan mengawasi kegiatan operasional perusahaan. (Marzuki. 2013)

UMKM dituntut untuk melakukan pengendalian internal dengan baik untuk mencapai efektifitas dan efisiensi. Selain itu, pengendalian internal juga dapat 
menghasilkan masukan untuk melakukan perbaikan-perbaikan. Manajemen bertanggung jawab untuk membentuk suatu lingkungan pengendalian pada perusahaannya. Hal ini merupakan bagian tanggung jawab mereka dalam penggunaan sumber daya yang dimiliki perusahaan. Manajemen harus memahami pentingnya menerapkan dan memelihara pengendalian secara efektif yang merupakan tanggung jawabnya. (Efendi, David. 2013)

Menurut COSO (Committee of Sponsoring Organization of the Treadway Commission) dalam bukunya Sawyer, 2012 yang berjudul Internal Auditing. Definisi pengendalian internal adalah suatu proses yang dilakukan oleh komisaris atau pemilik, manajemen dan karyawannya yang di desain untuk memberikan jaminan atas efektivitas dan efisiensi operasional perusahaan, laporan keuangan yang handal dan kepatuhan terhadap peraturan yang berlaku. Definisi tersebut memperjelas bahwa pengendalian internal bukan hanya mempengaruhi laporan keuangan yang reliabel tetapi juga menunjukkan bahwa pengendalian seharusnya efektif untuk semua kegiatan operasi. Dalam definisi tersebut juga diperjelas bahwa pengendalian internal dilakukan oleh seluruh jajaran direksi, manajemen dan karyawan.

Pengendalian internal dalam perusahaan sangat penting, dikarenakan semakin besar perusahaan, maka tingkat kinerja karyawan dalam perusahaan akan semakin tinggi. Oleh karena itu, diperlukan pengendalian internal yang efektif dan efisien untuk mencapai tujuan perusahaan. Menurut Efendi, David (2013), dimana kebutuhan yang mendorong perbuatan ke arah suatu tujuan yang diinginkan harus dimiliki manajer agar dapat memotivasi karyawan melakukan kinerja yang baik. Pada pernyataan tersebut mempunyai arti bahwa pengendalian internal dalam perusahaan dapat mempengaruhi kinerja karyawan, yang mana didalam komponen pengendalian internal mempunyai hubungan yang begitu penting sehingga perlu diperhatikan di dalam perusahaan.

Selain perlunya pengendalian internal dalam melaksanakan kegiatannya, UMKM pada umumnya sangat memerlukan sistem informasi akuntansi juga. Pengaruh perkembangan teknologi sekarang ini begitu pesat, oleh sebab itu setiap organisasi sekarang menganggap bahwa sistem informasi sangat penting bagi kelangsungan hidup perusahaan. Sistem informasi sangat erat kaitannya dengan akuntansi karena berguna untuk kegiatan operasional perusahaan khususnya dalam menyajikan informasi yang sesuai dengan kebutuhan manajemen maupun berbagai pihak diluar UMKM 
yang memerlukannya. Informasi memang menjadi unsur penentu dalam pengambilan keputusan, baik oleh manajemen perusahaan itu sendiri maupun pihak-pihak yang berkepentingan dengan UMKM.

Secara umum dapat dikatakan bahwa informasi yang objektif akan mendukung efisiensi. Demikian pula informasi akuntansi, apabila disajikan dengan bertolak pada sistem yang andal tentu akan menghasilkan informasi yang objektif. Oleh sebab itu, penugasan penyusunan sistem informasi akuntansi hendaknya selalu dilaksanakan dengan satu tujuan, yaitu agar informasi yang dihasilkan adalah informasi yang objektif sehingga mereka yang menggunakannya akan dapat mengambil keputusan dengan tepat. Menurut Hall (2011) sistem adalah sekelompok, dua atau lebih komponen yang saling berkaitan yang bersatu untuk mencapai tujuan yang sama. Suatu sistem harus memiliki tiga unsur yaitu input, proses dan output. Input merupakan penggerak atau pemberi tenaga dimana sistem itu dioperasikan. Output adalah hasil operasi. Dalam pengertian sederhana, output berarti yang menjadi tujuan, sasaran atau target pengorganisasian suatu sistem. Sedangkan proses adalah aktivitas yang mengubah input menjadi output.

Sistem tentunya sangat dibutuhkan untuk menopang suatu perusahaan agar tetap kokoh. Sistem adalah rangkaian dari dua atau lebih komponen-komponen yang saling berhubungan, yang berinteraksi untuk mencapai suatu tujuan (Romney dan Steinbart, 2014). Di dalam sebuah sistem, dialirkan informasi kepada tiap divisi yang ada di dalam perusahaan, selanjutnya divisi - divisi tersebut akan mengirimkan jawaban atas informasi yang telah dialirkan. Dalam satu kondisi, komponenkomponen yang ada dalam perusahaan dapat saling bertukar informasi sehingga terdapat suatu hubungan yang sinergis dalam sistem tersebut.

Tujuan dari sistem akuntansi adalah untuk memperbaiki pengendalian internal dan untuk memperbaiki informasi yang lebih baik, disamping untuk mengurangi biaya tata usaha atau biaya administrasi, dan untuk menentukan pelaksanaan proses produksi agar lebih mudah menjalankan perencanaan dan mencegah pelaksanaan operasional perusahaan yang kurang sehat. Sistem akuntansi juga merupakan alat kontrol perusahaan dalam menyelamatkan harta kekayaaan perusahaan.

Tujuan pemanfaatan sistem informasi terhadap kinerja karyawan lebih menekankan pada tingkat pengurangan kesalahan dalam memproses transaksi yang selama ini dilakukan secara manual dan memberikan informasi laporan yang akurat dan tepat waktu yang dapat 
digunakan oleh manajemen untuk membuat keputusan.

Salah satu fungsi penting sistem informasi akuntansi adalah pengendalian internal. Salah satu objek pengendalian internal adalah kinerja perusahaan dan kinerja individu didalamnya. Menurut Mangkunegara (2011) kinerja diartikan sebagai kualitas dan kuantitas dari hasil kerja yang telah dicapai oleh pegawai dalam melaksanakan tugasnya sesuai dengan tanggung jawabnya.

Pengukuran kinerja dapat menggunakan pendekatan "input-prosesoutput" dengan menggunakan indikator prestasi kerja, kerja sama, dan tanggung jawab (David, 2013). Indikator lain dapat juga digunakan sebagai alat ukur kinerja individu, yaitu kualitas kerja, kuantitas kerja, ketepatan waktu, tanggung jawab, pelaksanaan tugas, dan pengaruh rekan kerja (Mankunegara, 2011). Kinerja perlu dinilai untuk mengetahui tentang pelaksanaan tugas, seperti kesulitan yang dihadapi dan bagaimana penyelesaiannya, serta apakah tujuan atau organisasi telah tercapai.

Kinerja pada umumnya diartikan sebagai kesuksesan seseorang dalam melaksanakan suatu pekerjaan. Kinerja karyawan merupakan hasil kerja yang dicapai seseorang dalam melaksanakan tugas-tugas yang dibebankan kepadanya untuk mencapai target kerja. Karyawan dapat bekerja dengan baik bila memiliki kinerja yang tinggi sehingga dapat menghasilkan kerja yang baik. Kinerja karyawan merupakan salah satu faktor penentu keberhasilan perusahaan atau organisasi dalam mencapai tujuannya. Untuk itu kinerja dari para karyawan harus mendapat perhatian dari para pimpinan perusahaan, sebab menurunnya kinerja dari karyawan dapat mempengaruhi kinerja perusahaan secara keseluruhan. (Windi, Puspita Dian Sari Hasibuan. 2014).

Kinerja karyawan juga merupakan salah satu faktor yang dapat mempengaruhi produktivitas perusahaan. Kualitas manusia sebagai tenaga kerja merupakan modal dasar dalam masa pembangunan. Tenaga kerja yang berkualitas akan menghasilkan suatu hasil kerja yang optimal sesuai dengan target kerjanya. Tenaga kerja atau karyawan merupakan sumber daya yang penting bagi perusahaan, karena mereka mempunyai bakat, tenaga dan kreativitas yang sangat dibutuhkan oleh perusahaan untuk mencapai tujuannya. (Marlia Winiawati, 2015)

Upaya dalam hal meningkatkan kinerja karyawan dibutuhkan pengendalian internal dan sistem informasi akuntansi yang memadai sesuai dengan tingkat pekerjaan atau jabatan masing-masing 
karyawan. Dengan terbentuknya pengendalian internal yang kuat dan sistem informasi akuntansi yang sesuai, maka akan dapat membuahkan hasil atau kinerja yang baik sekaligus berkualitas dari pekerjaan yang dilaksanakannya.

Dalam penelitian ini peneliti menggabungkan dari dua jurnal yang meneliti tentang sistem informasi akuntansi dan pengendalian internal oleh peneliti dijadikan sebagai variabel independen dan yang menjadi variabel dependen yaitu kinerja karyawan. Berdasarkan hasil penelitian yang telah dilakukan oleh peneliti-peneliti sebelumnya dan karena pentingnya pengendalian internal dan sistem informasi akuntansi didalam suatu perusahaan serta pengaruhnya terhadap kinerja karyawan maka peneliti tertarik untuk melakukan penelitian dengan judul "PENGARUH PENERAPAN SISTEM INFORMASI AKUNTANSI DAN EFEKTIVITAS PENGENDALIAN INTERNAL TERHADAP KINERJA KARYAWAN (Studi Kasus Pada Usaha Mikro, Kecil, Menengah Kab. Subang)

\section{KERANGKA TEORITIS DAN PENGEMBANGAN HIPOTESIS}

\section{Efektivitas pengendalian Sistem}

Informasi Akuntansi

Menurut Susanto (2013) sistem informasi akuntansi pada dasarnya merupakan integrasi dari berbagai sistem pengolahan transaksi. Sistem informasi akuntansi dapat didefinisikan juga sebagai kumpulan (integrasi) dari sub sistem atau komponen baik fisik maupun non fisik yang saling berhubungan dan bekerja sama satu sama lain secara harmonis untuk mengolah data transaksi yang berkaitan dengan masalah keuangan menjadi informasi keuangan.

Menurut Romney \& Steinbart (2014:11) Sistem adalah serangkaian dua atau lebih komponen yang saling terkait dan berinteraksi untuk mencapai tujuan. Sebagaian besar sistem terdiri dari subsistem yang lebih kecil yang mendukung sistem yang lebih besar. Informasi adalah data yang telah dikelola dan diproses untuk memberikan arti dan memperbaiki proses pengambilan keputusan. Akuntansi adalah proses identifikasi, pengumpulan, dan penyimpanan data serta proses pengembangan, pengukuran, dan komunikasi informasi. Berdasarkan definisi diatas sistem informasi akuntansi (SIA) ialah mengumpulkan, memasukkan, memproses, menyimpan dan melaporkan data dan informasi menggunakan sistem manual pensil dan kertas, sistem kompleks yang menggunakan TI terbaru, atau sesuatu diantara keduanya.

Adapun Penjelasan mengenai komponen sistem informasi menurut Azhar Susanto (2013:208) sebagai berikut:

1. Perangkat Keras (Hardware)

Hardware merupakan peralatan phisik yang dapat digunakan untuk mengumpulkan, memasukkan, memproses, menyimpan dan 
mengeluarkan hasil pengolahan data dalam bentuk informasi.

2. Perangkat Lunak (Software)

Software adalah kumpulan dari programprogram yang digunakan untuk menjalankan aplikasi tertentu pada komputer, sedangkan program merupakan kumpulan dari perintahperintah komputer yang tersusun secara sistematis. Software dapat dikelompokkan menjadi dua kelompok berdasarkan fungsinya yaitu perangkat lunak sistem (sytem software) dan perangkat lunak aplikasi (application software).

3. Manusia (Brainware)

Brainware atau sumber daya manusia (SDM) SI/SIA merupakan bagian terpenting dari komponen sistem informasi (SI) dalam dunia bisnis yang dikenal sebagai sistem informasi akuntansi. Komponen SDM ini merupakan bagian yang tidak terpisahkan dengan komponen lainnya didalam suatu SI sebagai hasil dari perencanaan, analisis, perancangan, dan strategi implementasi yang didasarkan kepada komunikasi diantara sumber daya manusia yang terlinat dalam suatu ogranisasi.

\section{Prosedur (Procedure)}

Procedure adalah rangkaian aktivitas atau kegiatan yang dilakukan secara berulang-ulang dengan cara yang sama. Prosedur penting dimiliki bagi suatu organisasi agar segala sesuatu dapat dilakukan secara seragam. Jika prosedur telah diterima oleh pemakai sistem informasi maka prosedur akan menjadi pedoman bagaimana fungsi sistem informasi tersebut harus dioperasikan. Dengan adanya prosedur yang memadai maka pengendalian dapat dilakukan dengan baik.

\section{Basis Data (Database)}

Data adalah fakta baik dalam bentuk angka-angka, huruf-huruf atau apapun yang dapat digunakan sebagai input dalam proses untuk menghasilkan informasi.

6. Jaringan Komunikasi (Communication Network)

Jaringan komunikasi atau komunikasi data dapat didefinisikan sebagai penggunaan media elektronik atau cahaya untuk memindahkan data atau informasi dari satu lokasi ke satu atau beberapa lokasi lain yang bebeda. Komunikasi yang terjadi di antara beberapa pihak yang berkomunikasi harus difasilitasi dengan infrastruktur berupa jaringan telekomunikasi yang konfigurasinya bisa berbentuk bintang (star), cincin (ring), dan hirarki (BUS). 


\section{Pengendalian Internal}

Menurut Committee of Sponsoring Organizations of the Tradeway Commission (COSO, 2013) yaitu merupakan sistem, struktur atau proses yang diimplementasikan oleh dewan komisaris, manajemen dan karyawan dalam perusahaan yang bertujuan untuk menyediakan jaminan yang memadai bahwa tujuan pengendalian tersebut dicapai, yang meliputi efektifitas dan efisiensi operasi, keandalan pelaporan keuangan, dan kepatuhan terhadap peraturan perundangundangan dapat tercapai. Menurut Sinambela (2012), karena setiap organisasi didirikan untuk mencapai tujuan yang telah ditetapkan. Tujuan tidaklah bisa dicapai hanya oleh pimpinan atau pendiri organisasi saja akan tetapi pasti membutuhkan dukungan dan partisipasi orang lain atau pegawai. Ketika pegawai direkrut sudah tentu diberikan tanggungjawab pekerjaan yang harus diselesaikan.

COSO (2013) pengendalian internal meliputi kebijakan, aturan, dan prosedur yang ditetapkan oleh manajemen untuk memberikan keyakinan memadai bahwa laporan keuangan dapat diandalkan, operasi yang efektif dan efisien, dan kegiatan mematuhi hukum dan peraturan yang berlaku.Menurut AICPA (American Institute of Certified Public Acountant) memberikan definisi pengendalian internal adalah suatu sistem yang meliputi struktur organisasi, semua metode dan ketentuanketentuan yang berkoordinasi yang dianut dalam perusahaan untuk melindungi harta kekayaan, memeriksa ketelitian, dan seberapa jauh data akuntansi dapat dipercaya, meningkatkan efisiensi usaha dan mendorong ditaatinya kebijakan perusahaan yang telah ditetapkan.

Menurut Committee of Sponsoring Organizations of the Tradeway Commission (COSO) mendefinisikan ada lima komponen pengendalian internal yang berpengaruh terhadap kemampuan organisasi dalam mencapai sasaran pengendalian internal yaitu sebagai berikut:

1. Lingkungan Pengendalian

Mengacu pada faktor-faktor umum yang menetapkan sifat organisasi dan mempengaruhi kesadaran karyawannya terhadap pengendalian. Faktor-faktor ini meliputi integritas, nilai-nilai etika, serta filosofi dan gaya operasi manajemen. Juga meliputi cara manajemen memberikan wewenang dan tanggung jawab, mengantur dan mengembangkan karyawannya, serta perhatian dan arahan yang diberikan oleh dewan direksi.

2. Penentuan Risiko

Organisasi harus menyadari dan mengatasi resiko yang dihadapi. Organisasi harus menyusun tujuan, terintegrasi dengan penjualan, produksi, pemasaran, keuangan, dan aktivitas lain 
sehingga pelaksanaan organisasi berjalan harmonis. Perlu juga dibangun mekanisme untuk mengidentifikasi, menganalisis, dan mengatur resiko yang dapat terjadi.

\section{Aktivitas Pengendalian}

Prosedur dan kebijakan pengendalian harus dibangun dan dilaksanakan untuk membantu menjamin bahwa pelaksanaan diidentifikasi oleh manajemen sebagai sesuatu yang penting dalam mengatasi resiko dan pencapaian tujuan organisasi dilaksanakan secara efektif.

4. Informasi dan Komunikasi

Aktivitas pengendalian dikelilingi oleh sistem informasi dan komunikasi. Sistem informasi dan komunikasi memungkinkan personil dalam organisasi menangkap dan menukar informasi yang diperlukan untuk melaksanakan, mengatur, dan mengawasi pelaksanaan.

5. Pemantauan

Semua proses harus diawasi, dan modifikasinya sangat penting. Dengan pengawasan, sistem dapat beraksi secara dinamis, dan berubah sesuai dengan kondisi.

\section{Kinerja Karyawan}

Lijan Poltak Sinambela, dkk., (2016:480) mengemukakan bahwa kinerja pegawai didefinisikan sebagai kemampuan pegawai dalam melakukan sesuatu keahlian tertentu. Kinerja pegawai sangatlah perlu, sebab dengan kinerja ini akan diketahui seberapa jauh kemampuan mereka dalam melaksanakan tugas yang dibebankan kepadanya. Anwar Prabu Mangkunegara (2011:67) menyatakan bahwa Kinerja adalah hasil kerja secara kualitas dan kuantitas yang dicapai oleh seorang pegawai dalam melaksanakan tugasnya sesuai dengan tanggung jawab yang diberikan kepadanya.

Kinerja karyawan secara umum adalah sebuah perwujudan kerja yang dilakukan oleh karyawan yang biasanya digunakan sebagai dasar atau acuan penilaian terhadap karyawan didalam suatu organisasi. Kinerja yang baik merupakan suatu langkah untuk menuju tercapainya tujuan organisasi oleh karena itu, kinerja juga merupakan sarana penentu dalam mencapai tujuan organisasi sehingga perlu diupayakan untuk meningkatkan kinerja karyawan. Kamus besar bahasa Indonesia (2008:629) mendefinisikan karyawan adalah orang yang bekerja pada suatu lembaga (kantor, perusahaan, dsb) dengan mendapat gaji atau upah.

Anwar Prabu Mangkunegara (2011: 75) mengemukakan bahwa indikator kinerja, yaitu:

1. Kualitas Kerja 
Kualitas kerja adalah seberapa baik seorang karyawan mengerjakan apa yang seharusnya dikerjakan.

2. Kuantitas Kerja

Kuantitas kerja adalah seberapa lama seorang pegawai bekerja dalam satu harinya. Kuantitas kerja ini dapat dilihat dari kecepatan kerja setiap pegawai itu masing-masing.

3. Pelaksanaan tugas

Pelaksanaan Tugas adalah seberapa jauh karyawan mampu melakukan pekerjaannya dengan akurat atau tidak ada kesalahan.

4. Tanggung Jawab

Tanggung jawab terhadap pekerjaan adalah kesadaran akan kewajiban karyawan untuk melaksanakan pekerjaan yang diberikan perusahaan.

\section{Pengembangan Hipotesis}

Berdasarkan tujuan penelitian yang terdapat pada bab sebelumnya, peneliti membuat pengembangan hipotesis yang digambarkan ke dalam kerangka hipotesis pada gambar 2.2 berikut:

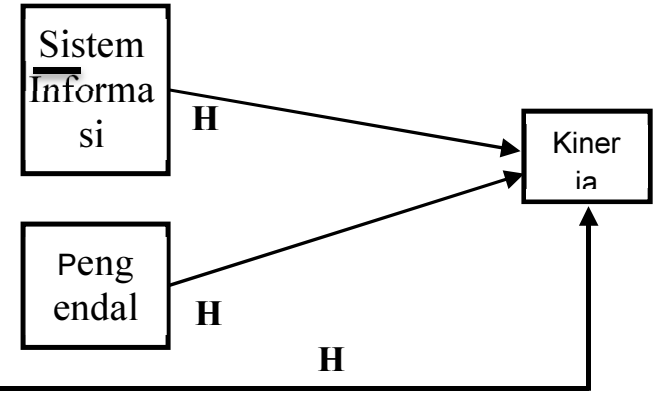

\section{Gambar 2.2 \\ Pengembangan Hipotesis}

Sumber: Penulis, 2017.

Berdasarkan uraian pada tinjauan pustaka dan gambar pengembangan hipotesis di atas, maka hipotesis yang dirumuskan sebagai berikut:

$\begin{array}{lrr}\text { H1: Sistem } & \text { Informasi } & \text { Akuntansi } \\ \text { Berpengaruh } & \text { Terhadap } & \text { Kinerja } \\ \text { Karyawan } & & \end{array}$

H2: Pengendalian Internal Berpengaruh Terhadap Kinerja Karyawan

H3: Sistem Informasi Akuntansi Pengendalian Internal Berpengaruh Terhadap Kinerja Karyawan

\section{METODOLOGI PENELITIAN}

Metode penelitian menurut Sugiyono (2016) adalah : "merupakan cara ilmiah untuk mendapatkan data dengan tujuan dan kegunaan tertentu." Terdapat empat kata kunci yang perlu diperhatikan yaitu, cara ilmiah, data, tujuan, kegunaan tertentu. Penelitian ini menggunakan metode kuantitatif yang melihat hubungan variabel terhadap objek yang diteliti lebih bersifat sebab akibat (kausal), sehingga terdapat variabel independen dan dependen.

Jenis data yang digunakan dalam penelitian ini adalah data kuantitatif dan data kualitatif. Data kuantitatif adalah data yang berbentuk angka atau data kualitatif yang diangkakan. Data kualitatif yang diangkakan 
(skoring) misalnya terdapat dalam skala pengukuran (Sugiyono, 2016). Pilihan pendekatan kualitatif dimaksudkan agar penelitian ini dapat memberikan penjelasan dan pemahaman yang menyeluruh.

Adapun sumber data yang dipergunakan dalam penelitian ini adalah data primer dan data sekunder sebagai berikut:

1. Menurut Sugiyono (2016) Data primer yaitu sumber data yang langsung memberikan data kepada pengumpul data.Data primer dalam penelitian ini adalah informasi yang dikumpulkan berdasarkan jawaban responden terhadap kuesioner.

2. Data yang digunakan dalam penelitian ini, selain menggunakan data primer juga menggunakan data sekunder. Data sekunder didapat dengan mengumpulkan data dari bahan-bahan atau sumber-sumber bacaan atau kepustakaan. Data sekunder diperoleh peneliti secara tidak langsung yaitu melalui media perantara (diperoleh dan dicatat oleh pihak luar) dengan mengunakan cara membaca dan mengutip baik secara langsung maupun tidak langsung dari literatur-literatur yang berhubungan dengan variabel penelitian.

Dalam suatu penelitian, teknik pengumpulan data perlu dilakukan secara berhati-hati, sistematis dan cermat, sehingga data yang dikumpulkan relevan dengan masalah penelitian yang akan dicari jawabannya sebagai upaya menguji kebenaran hipotesis yang telah dirumuskan. Untuk itu metode pengumpulan data yang digunakan dalam penelitian ini adalah sebagai berikut:

1. Kuesioner (angket), yaitu teknik pengumpulan data yang dilakukan dengan cara memberikan sejumah pertanyaan tertulis secara tersetruktur kepada responden penelitian berkaitan dengan tanggapannya terhadap bebagai variabel yang diteliti dalam penelitian ini. Kuesioner berupa pertanyaan terbuka dan tertutup.

2. Studi Kepustakaan, yaitu penelitian yang dilakukan dengan cara mendapatkan suatu keterangan masukan-masukan yang bersifat ilmiah yang didapat dari buku-buku, jurnal dan sebagainya, serta mencari pendapatpendapat yang bersifat teoritis dan relevan dengan objek pembahasan yang berhubungan dengan topik pengaruh sistem pengendalian intern dan kepuasan kerja terhadap kinerja karyawan studi kasus pada UMKM Kabupaten Subang. Sehingga diperoleh informasi sebagai dasar teori dan acuan untuk mengolah data-data yang diperoleh.

3. Wawancara, yaitu pengumpulan data dengan cara melakukan tanya jawab 
secara mendalam terhadap responden penelitian untuk memperoleh data yang lebih akurat dan lengkap karena menyangkut penjelasan lebih lanjut dari kuesioner yang telah dibagikan tersebut. Populasi dalam penelitian ini adalah pelaku Usaha Mikro, Kecil dan Menengah (UMKM) Kabupaten Subang. Sedangkan sampel dalam penelitian ini adalah pelaku usaha sektor menengah bidang jasa, perdagangan, pengolahan. Penulis memilih pelaku usaha sektor menengah karena pelaku usaha sektor menengah masuk ke dalam kriteria penelitian dan lebih memungkinkan untuk melakukan penyebaran kuesioner.

Untuk menentukan sampel yang akan digunakan dalam penelitian ini, peneliti menggunakan teknik non probability sampling dimana penulis menggunakan metode purposive sampling sebagai teknik pengambilan sampelnya. Purposive sampling adalah teknik penentuan sampel dengan pertimbangan atau kriteria tertentu (Sugiyono:2015:126). Adapun kriteria yang digunakan dalam penentuan sampel pada penelitian ini yaitu sebagai berikut:

Kriteria dalam penelitian ini mengacu pada Undang-Undang Nomor 20 tahun 2008, yang menyatakan bahwa pengertian Usaha Menengah sebagai berikut: Usaha Menengah, yaitu usaha ekonomi produktif yang berdiri sendiri, yang dilakukan oleh orang perorangan atau badan usaha yang bukan merupakan anak perusahaan atau cabang perusahaan yang dimiliki, dikuasi, atau menjadi bagian baik langsung maupun tidak langsung dengan usaha kecil atau usaha besar yang memenuhi kriteria, yaitu:

1) Memiliki kekayaan bersih lebih dari Rp. 500.000.000,- (Lima ratus juta rupiah) sampai dengan pling banyak Rp. 10.000.000.000,- (Sepuluh miliyar rupiah) tidak termasuk tanah dan bangunan tempat usaha.

2) Memiliki hasil penjualan tahunan lebih dari Rp. 2.500.000.000,- (Dua miliyar lima ratus juta rupiah) sampai dengan paling banyak Rp. 50.000.000.000,(Lima puluh miliyar rupiah).

\section{HASIL DAN PEMBAHASAN}

\section{Hasil Pengujian Validitas}

Hasil uji validitas untuk kuesioner independensi dengan $\mathrm{dk}$ atau $\mathrm{df}=100-2=$ 98 pada tingkat signifikansi $(\alpha) 5 \%$ atau 0,05 diperoleh $r_{\text {tabel }}=0.1966$ bahwa item-item kuesioner memiliki nilai $\mathrm{r}_{\text {hitung }}$ yang positif dan $r_{\text {hitung }}>r_{\text {tabel }}$ sebagai mana kriteria yang di tetapkan diatas. Hal ini menunjukan bahwa item-item ini sudah valid.

Dilakukan pengujian validitas untuk kuesioner semua variabel yang terdiri dari 37 butir pernyataan. Hasil pengujian menunjukan bahwa item-item pernyataan semua variabel sudah valid, sebab memiliki nilai rhitung positif dan $r_{\text {hitung }}>r_{\text {tabel. }}$ Untuk 
lebih jelasnya dapat dilihat pada tabel 4.12 dibawah ini:

Tabel 4.1

Hasil Uji Validitas Data

\begin{tabular}{|c|c|c|c|}
\hline $\begin{array}{c}\text { Variabel } \\
\text { X1 } \\
\end{array}$ & $\begin{array}{c}\text { rhitun } \\
\mathbf{g}\end{array}$ & rtabel & $\begin{array}{c}\text { Keteranga } \\
\text { n }\end{array}$ \\
\hline $\begin{array}{l}\text { Sistem } \\
\text { Informasi } \\
\text { Akuntansi } \\
1\end{array}$ & .405 & $\begin{array}{c}0,19 \\
7\end{array}$ & Valid \\
\hline $\begin{array}{l}\text { Sistem } \\
\text { Informasi } \\
\text { Akuntansi } \\
2\end{array}$ & .461 & $\begin{array}{c}0,19 \\
7\end{array}$ & Valid \\
\hline $\begin{array}{l}\text { Sistem } \\
\text { Informasi } \\
\text { Akuntansi } \\
3\end{array}$ & .434 & $\begin{array}{c}0,19 \\
7\end{array}$ & Valid \\
\hline $\begin{array}{l}\text { Sistem } \\
\text { Informasi } \\
\text { Akuntansi } \\
4\end{array}$ & .641 & $\begin{array}{c}0,19 \\
7\end{array}$ & Valid \\
\hline $\begin{array}{l}\text { Sistem } \\
\text { Informasi } \\
\text { Akuntansi } \\
5\end{array}$ & .557 & $\begin{array}{c}0,19 \\
7\end{array}$ & Valid \\
\hline $\begin{array}{l}\text { Sistem } \\
\text { Informasi } \\
\text { Akuntansi } \\
6\end{array}$ & .577 & $\begin{array}{c}0,19 \\
7\end{array}$ & Valid \\
\hline $\begin{array}{l}\text { Sistem } \\
\text { Informasi } \\
\text { Akuntansi } \\
7\end{array}$ & .577 & $\begin{array}{c}0,19 \\
7\end{array}$ & Valid \\
\hline $\begin{array}{c}\text { Variabel } \\
\text { X2 } \\
\end{array}$ & & & \\
\hline $\begin{array}{l}\text { Pengendali } \\
\text { an Internal } \\
1\end{array}$ & .264 & $\begin{array}{c}0,19 \\
7\end{array}$ & Valid \\
\hline $\begin{array}{l}\text { Pengendali } \\
\text { an Internal } \\
2\end{array}$ & .347 & $\begin{array}{c}0,19 \\
7\end{array}$ & Valid \\
\hline
\end{tabular}

\begin{tabular}{|c|c|c|c|}
\hline $\begin{array}{l}\text { Pengendali } \\
\text { an Internal } \\
3\end{array}$ & .345 & $\begin{array}{c}0,19 \\
7\end{array}$ & Valid \\
\hline $\begin{array}{l}\text { Pengendali } \\
\text { an Internal } \\
4\end{array}$ & .481 & $\begin{array}{c}0,19 \\
7\end{array}$ & Valid \\
\hline $\begin{array}{l}\text { Pengendali } \\
\text { an Internal } \\
5\end{array}$ & .456 & $\begin{array}{c}0,19 \\
7\end{array}$ & Valid \\
\hline $\begin{array}{l}\text { Pengendali } \\
\text { an Internal } \\
6\end{array}$ & .530 & $\begin{array}{c}0,19 \\
7\end{array}$ & Valid \\
\hline $\begin{array}{l}\text { Pengendali } \\
\text { an Internal } \\
7\end{array}$ & .412 & $\begin{array}{c}0,19 \\
7\end{array}$ & Valid \\
\hline $\begin{array}{l}\text { Pengendali } \\
\text { an Internal } \\
8\end{array}$ & .432 & $\begin{array}{c}0,19 \\
7\end{array}$ & Valid \\
\hline $\begin{array}{l}\text { Pengendali } \\
\text { an Internal } \\
9\end{array}$ & .466 & $\begin{array}{c}0,19 \\
7\end{array}$ & Valid \\
\hline $\begin{array}{l}\text { Pengendali } \\
\text { an Internal } \\
10\end{array}$ & .480 & $\begin{array}{c}0,19 \\
7\end{array}$ & Valid \\
\hline $\begin{array}{l}\text { Pengendali } \\
\text { an Internal } \\
11\end{array}$ & .517 & $\begin{array}{c}0,19 \\
7\end{array}$ & Valid \\
\hline $\begin{array}{l}\text { Pengendali } \\
\text { an Internal } \\
12\end{array}$ & .525 & $\begin{array}{c}0,19 \\
7\end{array}$ & Valid \\
\hline $\begin{array}{l}\text { Pengendali } \\
\text { an Internal } \\
13\end{array}$ & .472 & $\begin{array}{c}0,19 \\
7\end{array}$ & Valid \\
\hline $\begin{array}{l}\text { Pengendali } \\
\text { an Internal } \\
14\end{array}$ & .293 & $\begin{array}{c}0,19 \\
7\end{array}$ & Valid \\
\hline $\begin{array}{l}\text { Pengendali } \\
\text { an Internal } \\
15\end{array}$ & .443 & $\begin{array}{c}0,19 \\
7\end{array}$ & Valid \\
\hline $\begin{array}{l}\text { Pengendali } \\
\text { an Internal } \\
16\end{array}$ & .444 & $\begin{array}{c}0,19 \\
7\end{array}$ & Valid \\
\hline
\end{tabular}


Tabel 4.13

\begin{tabular}{|c|c|c|c|}
\hline Variabel Y & & & \\
\hline Kinerja & .30 & 0,19 & \\
\hline Karyawan 1 & 8 & 7 & Valid \\
\hline Kinerja & .34 & 0,19 & Volid \\
\hline Karyawan 2 & 6 & 7 & valla \\
\hline Kinerja & .29 & 0,19 & Volid \\
\hline Karyawan 3 & 5 & 7 & vanu \\
\hline Kinerja & .56 & 0,19 & \\
\hline Karyawan 4 & 4 & 7 & valla \\
\hline Kinerja & .50 & 0,19 & Vlid \\
\hline Karyawan 5 & 3 & 7 & valla \\
\hline Kinerja & .43 & 0,19 & Valid \\
\hline Karyawan 6 & 1 & 7 & vallu \\
\hline Kinerja & .47 & 0,19 & Volid \\
\hline Karyawan 7 & 9 & 7 & vanu \\
\hline Kinerja & .54 & 0,19 & Volid \\
\hline Karyawan 8 & 9 & 7 & valla \\
\hline Kinerja & .58 & 0,19 & Vlid \\
\hline Karyawan 9 & 3 & 7 & valla \\
\hline Kinerja & .60 & 0,19 & Volid \\
\hline Karyawan 10 & 1 & 7 & valla \\
\hline Kinerja & .59 & 0,19 & Valid \\
\hline Karyawan 11 & 6 & 7 & \\
\hline Kinerja & .52 & 0,19 & Volid \\
\hline Karyawan 12 & 1 & 7 & vallu \\
\hline Kinerja & .50 & 0,19 & Valid \\
\hline Karyawan 13 & 6 & 7 & valla \\
\hline Kinerja & .43 & 0,19 & Volid \\
\hline Karyawan 14 & 4 & 7 & valla \\
\hline
\end{tabular}

Sumber : Data Primer diolah, 2017

\section{Pembahasan}

\section{Pengaruh Sistem Informasi \\ Akuntansi Terhadap Kinerja \\ Karyawan}

Penelitian ini berhasil membuktikan seberapa besar suatu instrumen tersebut dapat di percaya dan digunakan sebagai alat pengumpul data. Hasil pengujian reabilitas dapat dilihat pada tabel 4.13 sebagai berikut:

\begin{tabular}{|l|c|c|}
\hline \multicolumn{1}{|c|}{ Variabel } & $\begin{array}{c}\text { Cronbach } \\
\text { 's Alpha }\end{array}$ & $\begin{array}{c}\text { Keteranga } \\
\mathbf{n}\end{array}$ \\
\hline $\begin{array}{l}\text { Sistem } \\
\text { Informasi } \\
\text { Akuntansi }\end{array}$ & $\begin{array}{c}0,808> \\
0,70\end{array}$ & Reliabel \\
\hline $\begin{array}{l}\text { Pengendalia } \\
\text { n Internal }\end{array}$ & $\begin{array}{c}0,825 \\
>0,70\end{array}$ & Reliabel \\
\hline Kinerja & 0,845 & Reliabel \\
Karyawan & $>0,70$ & \\
\hline
\end{tabular}

Sumber: Data Primer diolah, 2017

reliabilitas tersebut menunjukan bahwa semua variabel yang dijadikan instrumen adalah reliabel atau dapat dipercaya dan dapat digunakan sebagai alat pengumpul data sebab nilai cronbach's alpha $>0,70$ yang artinya data yang dipakai sudah termasuk dalam reliabel dan layak digunakan sebagai alat ukur dalam pengujian statistik. Realiabilitas yang semakin tinggi menunjukan hasil ukur yang didapatkan semakin terpercaya.

adanya pengaruh sistem informasi akuntansi terhadap kinerja karyawan. Hal ini menunjukan besarnya nilai signifikansi < 0,05 , akan lebih kecil dari $\alpha=5 \%$ yaitu 
sebesar 0,000 , dan nilai $t_{\text {hitung }}>t_{\text {tabel }}$ dengan $t_{\text {hitung }}$ sebesar 8.567 dan tabel sebesar 1.985 dan $t_{\text {hitung }}$ bernilai positif sehingga hipotesis pertama diterima. Hal ini menunjukan bahwa penerapan sistem informasi akuntansi sangat baik. Hasil penelitian ini sejalan dengan penelitian sebelumnya yang dilakukan Fahmi Rizaldi (2015) dengan hasil penelitian yang membuktikan bahwa adanya pengaruh sistem informasi akuntansi terhadap kinerja karyawan. Jadi, berdasarkan hasil di atas sistem informasi akuntansi berpengaruh positif secara signifikan terhadap kinerja karyawan. Artinya jika sistem informasi akuntansi sudah memadai sesuai dengan tingkat pekerjaan atau jabatan masing-masing, maka akan meningkatkan kinerja karyawan.

\section{Pengaruh Pengendalian Internal}

\section{Terhadap Kinerja Karyawan}

Penelitian ini berhasil membuktikan adanya pengaruh pengendalian internal terhadap kinerja karyawan. Hal ini menunjukan besarnya nilai signifikansi < 0,05 , akan lebih kecil dari $\alpha=5 \%$ yaitu sebesar 0,000 , dan nilai $t_{\text {hitung }}>t_{\text {tabel }}$ dengan $t_{\text {hitung }}$ sebesar 3.705 dan $t_{\text {tabel }}$ sebesar 1,985 dan thitung bernilai positif sehingga hipotesis kedua diterima. Hal ini menunjukan bahwa efektivitas pengendalian internal sangat baik. Hasil penelitian ini sejalan dengan penelitian sebelumnya yang dilakukan Siti
Lailis Shoimah (2015) dengan hasil penelitian membuktikan bahwa adanya pengaruh pengendalian internal terhadap kinerja karyawan. Jadi, berdasarkan hasil di atas pengendalian internal berpengaruh positif secara signifikan terhadap kinerja karyawan. Artinya dengan terbentuknya pengendalian internal yang kuat maka akan membuahkan hasil atau kinerja yang baik sekaligus berkualitas dari pekerjaan yang dilaksanakannya.

\section{Pengaruh Sistem Informasi Akuntansi dan Pengendalian Internal Terhadap Kinerja Karyawan}

Dari hasil uji-F diatas dapat disimpulkan bahwa variabel sistem informasi akuntansi dan pengendalian internal secara simultan berpengaruh signifikan terhadap kinerja karyawan. Hal ini dibuktikan dengan fitung sebesar 65.436 lebih besar dari $f_{\text {tabel }}$ yaitu 3,09 dengan probabilitas $=0.000$. dari hasil tersebut, maka diketahui bahwa $f_{\text {hitung }}>f_{\text {tabel, }}$ artinya variabel sistem informasi akuntansi dan pengendalian secara simultan berpengaruh signifikan terhadap kinerja karyawan. Artinya semakin baik penerapan sistem informasi akuntansi serta pengendalian internal yang efektif maka kinerja karyawan semakin meningkat. 


\section{KESIMPULAN}

Berdasarkan hasil pengujian hipotesis dan mengacu pada identifikasi masalah penelitian ini, dapat ditarik kesimpulankesimpulan sebagai berikut:

1. Penerapan sistem informasi akuntansi di usaha sektor menengah bidang jasa, pengolahan, dan perdagangan Kabupaten Subang dikategorikan baik, dimana skor yang didapat termasuk ke dalam kriteria baik. Penerapan sistem informasi akuntansi secara parsial berpengaruh signifikan positif terhadap kinerja karyawan.

2. Efektivitas pengendalian internal di usaha sektor menengah bidang jasa, pengolahan, dan perdagangan Kabupaten Subang dikategorikan baik, hal ini dapat dilihat dimana skor yang didapat termasuk ke dalam kriteria baik. Efektivitas pengendalian internal secara parsial berpengaruh signifikan positif terhadap kinerja karyawan.

3. Secara simultan Penerapan sistem informasi akuntansi dan Efektivitas pengendalian internal berpengaruh signifikan terhadap kinerja karyawan di usaha sektor menengah bidang jasa, pengolahan, dan perdagangan Kabupaten Subang.

\section{Keterbatasan}

Adapun keterbatasan dalam penelitian ini adalah sebagai berikut :

1. Dalam penelitian ini sampel yang digunakan peneliti hanya kepada para pelaku usaha sektor menengah bidang jasa, pengolahan, dan perdagangan di Kabupaten Subang saja.

2. Dalam penelitian ini juga faktor-faktor yang mempengaruhi variabel dependen hanya menggunakan dua variabel independen yaitu terdiri dari sistem informasi akuntansi dan pengendalian internal.

\section{Saran}

Berdasarkan kesimpulan diatas, maka dapat diajukan beberapa saran dari hasil penelitian yang diperoleh, yaitu:

1. Berdasarkan hasil penelitian yang diperoleh dari data kuesioner yang didapat dari 100 responden pelaku usaha sektor menengah bidang jasa, pengolahan, perdagangan di Kabupaten Subang dan sehubungan dengan variabel-variabel yang diteliti tentang pengaruh penerapan sistem informasi akuntansi terhadap kinerja karyawan, maka saran yang dapat disampaikan oleh peneliti kepada para pelaku usaha sektor menengah bidang jasa, pengolahan, dan perdagangan di Kabupaten Subang adalah harus bisa 
memahami pentingnya menerapkan sistem informasi akuntansi, karena sistem informasi akuntansi tentunya sangat dibutuhkan bagi kelangsungan hidup UMKM dan untuk menopang suatu UMKM agar tetap kokoh.

2. Mengingat variabel pengendalian internal juga berpengaruh terhadap kinerja karyawan maka diharapkan bagi UMKM untuk melakukan pengendalian internal dengan baik untuk mencapai efektifitas dan efisiensi. Karena pengendalian internal merupakan suatu cara untuk mengarahkan, mengawasi dan mengukur sumber daya perusahaan. Jadi untuk meningkatkan kinerja karyawan dibutuhkan pengendalian internal yang baik dan sistem informasi akuntansi yang memadai sesuai dengan tingkat pekerjaan atau jabatan masingmasing karyawan.

3. Untuk pelaku usaha sektor menengah bidang jasa, pengolahan, dan perdagangan di Kabupaten Subang, diharapkan agar selalu mengadakan pelatihan terencana secara rutin dan mendorong seluruh karyawannya untuk melanjutkan jenjang pendidikan agar dapat lebih memahami tentang sistem informasi akuntansi yang digunakan oleh UMKM dan dalam pemilihan sistem informasi yang akan digunakan oleh UMKM harus tepat guna dan benar-benar dibutuhkan oleh UMKM tersebut.

4. Untuk penelitian selanjutnya disarankan agar memperluas sampel yang tidak terbatas pada satu daerah saja

Untuk penelitian selanjutnya, sebaiknya menambah variabel independen, variabel moderating, dan variabel intervening untuk mengetahui variabel-variabel lain yang dapat mempengaruhi dan memperkuat atau memperlemah variabel dependen. Seperti gaya kepemimpinan, kompensasi, motivasi kerja, budaya organisasi, komitmen organisasi, disiplin kerja, kepuasan kerja

\section{DAFTAR PUSTAKA}

\section{Peraturan}

Undang-Undang Nomor 20 tahun 2008 tentang Usaha Mikro Kecil Menengah

\section{Jurnal dan Skripsi}

A. Hall. James. 2011. Sistem Informasi Akuntansi. Buku 1 Edisi 4. Jakarta: Salemba Empat.

Anwar Prabu Mankunegara. 2011. Manajemen Sumber Daya Manusia Perusahaan. Bandung: PT. Remaja Rosda Karya.

Azhar Susanto. 2013 Sistem Informasi Akuntansi (Struktur, Pengendalian, Resiko, Pengembangan). Edisi pertama. Bandung: Lingga Jaya

B. Romney, Marshall \& John Steinbart Paul. 2014. Accounting Information Systems, 13th Edition. Jakarta: Salemba Empat. 
Imam Ghozali. 2013. SPSS 21 Analisis Multivariate dengan Program SPSS.

Badan Penerbit Universitas

Diponegoro: Semarang.

Imam Ghozali. 2016. Aplikasi Analisis Multivariat dengan Program IBM SPSS 23. Semarang: Penerbit Universitas Diponegoro.

Krismiaji. 2010. Sistem Informasi Akuntansi. Edisi Ketiga. UPP-STIM YKPN. Yogyakarta. Hal 4-5.

Lijan Poltak Sinambela. 2016. Manajemen

Sumber Daya Manusia. Jakarta: Bumi Aksara.

Mardi. 2011. Sistem Informasi Akuntansi.

Bogor: Ghalia Indonesia.

Samiaji Sarosa. 2009. Sistem Informasi

Akuntansi. Jakarta: Grasindo.

Sugiyono. 2014. Metode Penelitian Pendidikan (Pendekatan Kuantitatif, Kualitatif dan R\&D). Bandung: Alfabeta.

Sugiono.2016. Metode Penelitian Kombinasi (Mixed Methods). Bandung: Alfabeta.

Sawyer, B. Lawrence et al. 2012.Internal Auditing, Edisi 6. Florida: The Institute Of Internal Auditors. Terjemahan Desi Adhariani. Jakarta: Salemba Empat.

Astuti, Ni made Marlita Puji dan Ida Bagus

Dharmadiaksa. 2014. "Pengaruh Efektivitas Sistem Informasi Akuntansi, Pemanfaatan dan Kesesuaian Tugas pada Kinerja Karyawan”. ISSN: 2302-8556 E-Jurnal Akuntansi Universitas Udayana. 9.2 (2014): 373-384

COSO. 2013. Internal Control - Intergrated Framework : Execitive Summary.

Durham. North Carolina, May 201

Dewi, Permata. 2012. Pengaruh Pengendalian Intern dan Gaya Kepemimpinan
Terhadap Kinerja Karyawan SPBU Yogyakarta. Yogyakarta. Jurnal. Vol

1. No 1. Hal 67

Efendi, David. 2013. Pengaruh Sistem Informasi Akuntansi Dan Kinerja

Karyawan Terhadap Keefektifan Pengendalian Internal Di Koperindo Jatim

Cabang Nganjuk. Universitas Muhammadiyah Ponorogo, Prodi S1 Akuntansi.

Fahmi Rizaldi. 2015. Pengaruh Sistem Informasi Akuntansi Terhadap Kinerja Karyawan CV Teguh Karya Utama Surabaya.Jurnal Ilmu \& Riset Akuntansi Vol. 4 No. 10.Sekolah Tinggi Ilmu Ekonomi Indonesia (STIESIA) Surabaya.

Fahmi. 2009. Analisis Pengaruh Gaya Kepemimpian dan Motivasi Kerja terhadap Kinerja Pegawai SPBU Pandanaran Semarang. Jurnal. Universitas Gunadarma.

Kadek Wahyu Indralesmana dan I.G.N. Agung Suaryana (2014). Pengaruh Penerapan Sistem Informasi Terhadap Kinerja Individu Pada Usaha Kecil dan Menengah Di Nusa Penida ISSN: 2302-8556 E-Jurnal Akuntansi Universitas Udayana 8.1 (2014): 14-26 Linda Oktarnia. 2014. Pengaruh Pengendalian Internal Terhadap Kinerja Karyawan Pada Bidang Keuangan Rumah Sakit Tanjung Pinang Dan Bintan.Jurnal.Universitas Maritim Raja Ali Haji.

Maharani, Farisa Lailatul. 2015. Pengaruh Pengendalian Terhadap Kinerja Karyawan pada Divisi Pelayanan Medis Di Rumah Sakit Jember Klinik. Skripsi Universitas Jember.

Marzuki. 2013. Pengaruh Pengendalian Intern, Sistem Akuntansi Manajemen, dan Kapasitas Sumber Daya Manusia 
terhadap Kinerja Manajerial pada Lembaga Keuangan Mikro di Kota Banda Aceh dan Kabupaten Aceh Besar. Jurnal Akuntansi Universitas Abulyatama. Banda Aceh.

Marlia Winiawati. 2015. Pengaruh Pengendalian Internal dan Gaya Kepemimpinan terhadap Kinerja Karyawan pada SPBU Surakarta Jurnal Universitas Muhammadiyah Surakarta. Mitchael Hutomo Tanuwibowo dan Roy Setiawan.2015. Pengaruh Budaya Organisasi dan Motivasi Kerja terhadap Kinerja Karyawan pada PT. Lestari Purnama Perkasa.AGORA Vol. 3, No. 2.Universitas Kristen Petra.

Ni Putu Eka Suranti, Ni Kadek Sinarwati \& Ananta Wikrama Tungga Atmadja.2015. Pengaruh Efektivitas Sistem Informasi Akuntansi dan Penggunaan Teknologi Informasi Akuntansi tehadap Kinerja Individual pada PT. Bank Pembangunan Daerah Bali Kantor Cabang Singaraja.eJournal SI Ak Vol. 3, No. 1. Universitas Pendidikan Ganeshaa Singaraja.

Salamah, L. 2010. Lingkaran Krisis Ekonomi Indonesia. Jurnal Masyarakat Kebudayaan dan Politik. Volume 14, Nomor 2: 65-76.

Sheilla Puteri Suhud. 2015. Pengaruh Penerapan Sistem Informasi Akuntansi Terhadap Kinerja Individu Pegawai Distro di Kota Bandung. Jurnal. Universitas Diponegoro.

Siti Lailis Shoimah. 2015. Pengaruh Pengendalian Internal terhadap Kinerja Karyawan Hotel di Kabupaten Jember. Jurnal Artikel Ilmiah Mahasiswa 2015. Universitas Jember.

Windi, Puspita Dian Sari Hasibuan. 2014. Pengaruh Motivasi dan Lingkungan
Kerja Terhadap Kinerja Karyawan Pada PT. Perkebunan Nusantara IV Kantor Pusat, Medan.Skripsi. Universitas Sumatera Utara.

Willya Randika. 2013. Pengaruh Sistem Informasi Akuntansi Terhadap Kinerja Perusahaan Pada Usaha Mikro, Kecil dan Menengah (UMKM). Skripsi. Jakarta: Universitas Islam Negeri Syarif Hidayatullah. 